\title{
Qualitative analysis of Phytochemical studies on Sargassum wightii and Padina gymnospora
}

\author{
Maria Puspham Grace ${ }^{1}$, M Rajithra R $^{2}$, V.Ilakkiya ${ }^{3}$, Dr.B.Dhanalakshmi ${ }^{4}$ \\ ${ }^{1234}$ Department of Zoology, Nirmala College for Women, Bharathiyar University, Coimbatore-18
}

\begin{abstract}
In recent years, the secondary metabolites are extensively investigated as a supply of healthful agents. The sample for the study constitutes Sargassum wightii and Padina gymnospora and it was collected from the Mandapam coast, Rameswaram, TamilNadu, India. Sargassum wightii is belonging to the family Sargassum wightii and Padina gymnospora belonging to the family Dictyotaceae are 2 brown seaweeds betterknown for varied biological activities like bactericide, antiviral, inhibitor, opposed cancer, medicine, etc. Five totally different extracts of Sargassum wightii and Padina gymnospora were subjected to phytochemical analysis of secondary metabolites of qualitatively phytochemical screening tests of twelve different chemical compounds (alkaloids, terpenoids, steroids, tannins, saponins, flavonoids, phenols, coumarins, proteins, sugars, quinones, and glycosides). Among the solvent extracts of alga Sargassum wightii and Padina gymnospora showed the utmost presence of saponins, carbohydrates, proteins, and quinines in 3 completely different extracts (ethanol, methanol, water) except solvent and chloroform. So the present study on extractive values of methyl alcohol extract and the binary compound extract was most in each the seaweeds, however, were significantly a lot of in P. gymnopora than S. wightii. Considering their therapeutic uses, like alternative healthful plants there's a requirement to try pharmacognostic studies of those 2 seaweeds.
\end{abstract}

KEYWORDS: Seaweeds, Coumarins, Phytochemicals, Sargassum wightii and Padina gymnospora

\section{INTRODUCTION}

Brown seaweed area unit used as animal feed, food ingredients, and fertilizers. They're additionally sensible sources of proteins, carbohydrates, vitamins, and minerals. Food reserves of algae area unit usually complicated polysaccharides and better alcohols. several bioactive metabolites are isolated from algae with totally different medical specialty activities like cytotoxic and antineoplastic, antifungal, antifeedant, inhibitor medicinal drug, antiviral, hepatoprotective, algicidal, anti-diabetic, medicament, nematocidal, etc. (El Gamal AA.,2010). sargasso wightii J. Agardh is one in all the marine macro protoctist happiness to the category Phaeophyceae; it's cosmopolitan in tropical and temperate oceans. It belongs to the marine family Sargassaceae and animal order. It's referred to as sargasso or ocean holly. 
It's an oversized, affordably vital, and ecologically dominant algae gift in a lot of the tropics. It's the foremost numerous genus among division Phaeophyta in Asian country and is diagrammatical by thirty-eight species.

Another genus Padina belongs to the category Phaeophyceae and order dictyotales. Padina gymnospora (Kutzing) Sonder belongs to the family Dictyotaceae. Its common name is funnelweed. It's a good vary of bioactive properties like medicament activity (Silva, 2005); haemagglutinating and cytotoxic activity (Joshi et al., 2012); antimicrobial and hemolytic activity (Chander et al., 2014); inhibitor activity (Murugan et al., 2014); Plant growth-promoting impact (Hernández et al., 2016); would heal property (Baliano et al., 2016); synthesis of noble metal nanoparticles (Sri Ramkumar et al., 2017); cytotoxic activity (. Awad et al., 2008 \& Jaswir et al., 2011); antimicrobial activity (. Rangaiah et al., 2010) and medicine activity (. El Shoubaky et al., 2014).

Phytochemicals like polyphenols, that area unit broadly speaking showing in plants, area unit found to act as atom scavengers and antimicrobial agents (Gulcin et al., 2002; Oktay et al., 2003). Marine plants contain high amounts of polyphenols and consequently, seaweeds will be used as effective natural antioxidants. Seaweeds area unit utilized for its made nutrient content and inhibitor property in treating major chronic and deficiency diseases. Hence it's vital and necessary to try pharmacognostic studies of marine protoctist. There are a unit some reports of the pharmacognostic study of protoctist for eg. pharmacognostic and phytochemical investigation of designated marine seaweeds of class Rhodophyceae (. Adikalaraj et al., 2011); pharmacognostic and phytochemical analysis of sargasso wightii from Gulf of Mannar, Mandapam coastal regions Tamilnadu is according by Devi et al., (Devi et al., 2013); whereas pharmacognostic and phytochemical studies of sargasso ilicifolium from Rameshwaram coast, Chennai is according by Sumithra and Arunachalam (Sumithra et al., 2014). We've according to the pharmacognostic study of 2 algae Chaetomorpha antennina and Ulva asterid dicot genus (. Dhanki et al., 2018)and within the gift work; we have a tendency to report the pharmacognostic study of 2 algae sargasso wightii and Padina gymnospora. 


\section{MATERIALS AND METHODS}

\section{Collection of seaweeds}

Seaweed was collected during the lowest tide of chart datum from the seaweed infested locations along the Southeast coast of India, Rameswaram $\left(9.288^{\circ} \mathrm{N}\right.$ and $\left.79.313^{\circ} \mathrm{E}\right)$ Ramnadu district, Tamilnadu, India. The macroalgae which infested exclusively on the intertidal rocky and other substratum was selected for the collection as to avoid other microalgal contamination. The seaweed samples were collected from spots like Mandapam (Latitude: 9.2770392 and Longitude: 79.1252174) and Pamban bridge (Latitude: 9.2761; Longitude: 79.1867.) of Rameswaram East coast of Tamilnadu, India. The live and healthy macro algal sample was collected by handpicking method at a depth of 1-2m during the month Dec 2020, from sandy beaches and irregularly distributed rocky substratum, of Mandapam beach and Pamban bridge of Rameswaram, Ramnad District, Tamilnadu, India.

\section{Preservation of seaweeds:}

Immediately after collection the surface of seaweed was washed to avoid other algal contamination. They were washed in fresh sea water to eliminate the epiphytes, extraneous matter course sand and other calcareous impurities from the Pamban Bridge and Mandapam area of Rameswaram, Ramnadu district Tamilnadu, India. The collected macroalgae samples are transported to the laboratory in polythene bags under ice at $20^{\circ} \mathrm{C}$ to avoid decomposition and loss of metabolites for identification and future reference.

\section{Identification of macroalgae}

The seaweed thus collected was identified with the help of seaweed taxonomist in Centre for Marine Fisheries Research Institute (CMFRI) Mandapam camp Tamilnadu, India (Plates: 1\&2) 


\title{
Scientific classification of identified seaweed
}

\section{Study Species: I}

\author{
Domain : Eukaryota \\ Phylum : Heterokontophyta \\ Class : Phaeophyceae \\ Order : Fucales \\ Family :Sargassaceae
}

Genus :Sargassum

Species :Sargassum wightii(Greville)

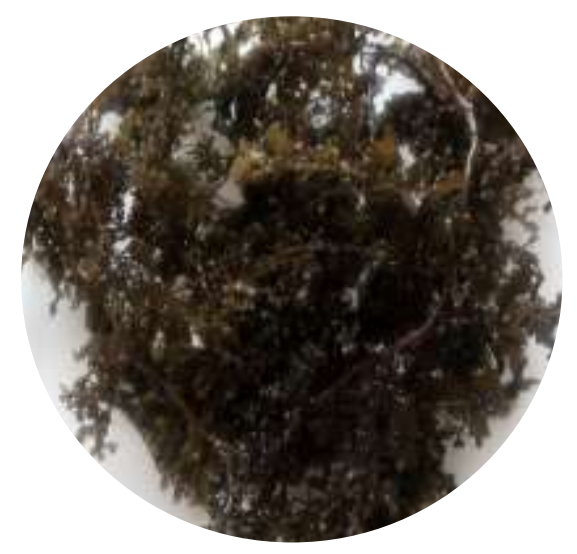

Plate: 1 Sargassum wightii

Common name: Gulf weed

Environment: Coral reefs, subtidal,

Climate / Range: Tropical

Distribution: Africa, Kenya; Indian Ocean Islands: Andaman Islands, Christmas Island, Indian Ocean, Nicobar Islands, South-west Asia: Bangladesh, India, Sri Lanka; Asia: China, South China Sea; South-east Asia: Malaysia

Short description: The algae are free floating and brown in colour, commonly found in tropical seas. Species of this genus of algae may grow to a length of several metres. They are generally brown or dark green in color and consist of a holdfast, a stipe, and a frond. The plant body is diploid and differentiated into root, stem and leaf-like structures. The leaves are flat, simple structures with distinct midrib and dentate, serrate or entire margins, with an acute apex. It bears long shoots of unlimited growth (primary laterals), leaves (secondary laterals), air bladders and receptacles. Some species have berrylike gas-filled bladders which 
help keep the fronds afloat to promote photosynthesis. Many have a rough sticky texture, which together with a robust but flexible body, helps it to withstand strong water currents (Plate: 1).

\section{Study Species: II}

Domain : Eukaryota
Phylum : Ochrophyta
Class : Phaeophyceae

Order :Dictyotales

Family :Dictyotaceae

Genus : :Padina

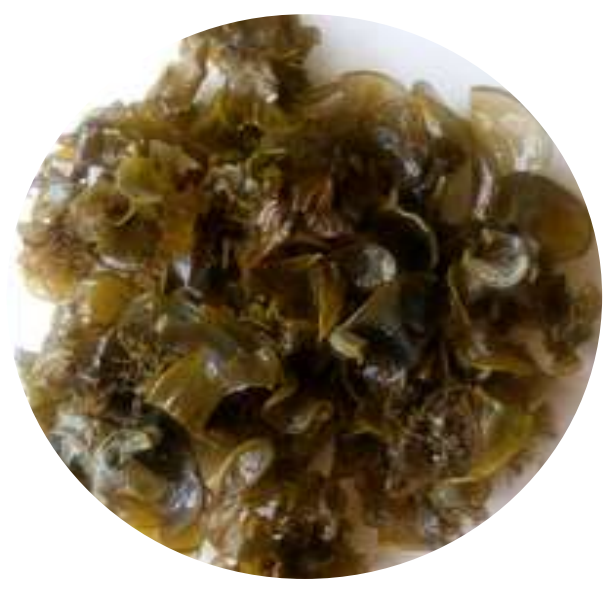

Species :Padina gymnospora (Kutzing)

Plate: 2 Padina gymnospora

Common name: Funnel weed

Environment: Sessile; brackish; depth range 0 - 14 m

Climate / Range: Tropical

Distribution: Atlantic Ocean Gulf of Mexico, Caribbean and Bermuda, the Mediterranean (Israel), Canary, Cape Verde and Ascension Island; Indian Ocean, Persian Gulf, Seychelles, Madagascar and Réunion, east to India and south to Western Australia including Bay of Bengal and Andaman Sea; Pacific Ocean: from Korea to the South China Sea south to Queensland, Australia

Short description: Thalli, attached by a small stupose rhizoidal base, are to $6.5 \mathrm{~cm}$ high, flabellate and composed of several lobes with in rolled margins. The superior surface (the side toward which the margin is in rolled) is slightly to moderately calcified. Thalli are olivebrown in colour. In transverse section the thallus is composed of 4-6 layers of cells in the mid-regions and up to 8-9 layers near the base. Hair rows are present on both sides of the 
thallus, but more conspicuous on the inferior side of the thallus. Tetrasporangia are arranged in concentric lines, above each hair row, mainly (but not exclusively) developed on the superior surface. An evanescent indusium is present but is usually only clearly visible in very young sori. Tetrasporangia are ovoid, up to $100 \mu \mathrm{m}$ long and $70 \mu \mathrm{m}$ wide. (Plate: 2 ).

\section{Preparation of powder}

The identified species washed thoroughly with tap water until unwanted impurities, adhering sand particles and extraneous matter like epiphytes, pebbles, surface salty matures shells, were removed and rinsed with sterile distilled water spread on filter paper and left few hours to absorb the excess water and then cut into small pieces, shade dried for two weeks and later the samples were made into coarse powder by grinding them in an lab electric mixer grinder. The powdered sample were then stored in refrigerator. They were then screened for the evaluation of their phytochemical screening and antibacterial activity.

\section{Extraction of shade dried plant material}

The secondary metabolites were extracted by using soxhelt apparatus. The algal power was mixed with different solvents with increasing polarity Chloroform, Ethanol, Methanol, Acetone and Water (1:5 w/v) and placed into a soxhlet apparatus at $50^{\circ} \mathrm{C}$ for $24 \mathrm{hrs}$ the extraction was filtered using whatman No 1 filter paper. After extraction was complete, the solvent was then evaporated under vaccum and then the residue crude obtained was stored in a freezer at $-20^{\circ} \mathrm{C}$ for preliminary phytochemical analysis and antibacterial assay. (Becerro et al., 1988; Murugan and Santhanaramasamy, 2003; Kanjana et al., 2011; Krishnaveni et al., 2012;).

\section{Preparation of seaweed solvents extract on phytochemical screening}

The dried, powered sample was subjected to qualitative test for the amount of phytochemicals present in the collected algal samples for identification of phytochemical constituents according to standard procedures (Lala, 1993).

\section{Phytochemical analysis in different solvent extract}

The phytochemical analysis of chloroform, ethanol, methanol, acetone and water extract from selected algae were screened for the presence or absence of active secondary 
metabolities such as alkaloids, phenols, flavonoids, anthraquinones, tannins, saponins, coumarins, carbohydrate, proteins, quinines, glycosides and terpenoids. General reaction in these analyses revealed the presence or absence of the compounds in the algal extracts in following procedures. The phytochemicals of the extracts were determined qualitatively as reported by (Trease and Evans, 1989; Sadasivam and Manickam, 1996).

\section{Test for Alkaloids:}

$1 \mathrm{ml}$ of $1 \% \mathrm{HCl}$ was added to $3 \mathrm{ml}$ of extract in a test tube and was treated with few drop of Meyer's reagent. A creamy white precipitate indicted the presence of alkaloids.

\section{Test for Phenols:}

Ferric Chloride Test: Extracts were treated with 3-4 drops of ferric chloride solution. Formation of bluish black colour indicates the presence of phenol.

\section{Test for Flavonoids:}

A few drops of $1 \% \mathrm{NH}_{3}$ solution was added to the extract in a test tube. A yellow coloration was observed for the presence of flavonoids.

\section{Test for Anthraquinones:}

For Anthraquinone identification, $1 \mathrm{ml}$ of plant extract few drops of $10 \%$ ammonia solution was added, appearance of pink color precipitate indicates the presence of anthraquinones.

\section{Test for Tannins:}

To $0.5 \mathrm{ml}$ of extract solution, $1 \mathrm{ml}$ of distilled water and 1-2 drops of ferric chloride solution were added and observed for brownish green or a blue black coloration.

\section{Test for Saponins:}

$5 \mathrm{ml}$ of extract was shaken vigorously to obtain a stable persistent froth. The frothing was then mixed with 3 drops of olive oil and observed for the formation of emulsion, which indicated the presence of saponins. 


\section{Test for Coumarins:}

For coumarins identification, $1 \mathrm{ml}$ of extract, $1 \mathrm{ml}$ of $10 \% \mathrm{NaOH}$ was added. Formation of yellow colour indicates presence of coumarins.

\section{Test for Carbohydrates:}

Mix $2 \mathrm{ml}$ of plant extract, $1 \mathrm{ml}$ of molisch's reagent and few drops of conc. Sulphuric acid were added. Purple or reddish color indicates the presence of carbohydrates.

\section{Test for Proteins:}

To $2 \mathrm{ml}$ of extract $1 \mathrm{ml}$ of $40 \% \mathrm{NaOH}$ solution and 2 drops of $1 \% \mathrm{CuSo}_{4}$ solution was added. A violet color indicates presence of peptide linkage molecule.

\section{Test for Quinones:}

For quinines identification, $1 \mathrm{ml}$ of extract, $1 \mathrm{ml}$ of concentrated sulphuric acid was added. Formation of red color indicates presence of quinines.

\section{Test for Glycosides:}

$10 \mathrm{ml}$ of $50 \% \mathrm{H}_{2} \mathrm{SO}_{4}$ was added to $1 \mathrm{ml}$ of extract in a boiling tube. The mixture was heated in boiling water for $5 \mathrm{~min}$. $10 \mathrm{ml}$ of Fehling's solution ( $5 \mathrm{ml}$ of each solution A and B) was added and boiled. A brick red precipitate indicated presence of glycosides.

\section{Test for Terpenoids:}

$5 \mathrm{ml}$ of extract was mixed with $2 \mathrm{ml}$ of $\mathrm{CHCl}_{3}$ in a test tube. $3 \mathrm{ml}$ of concentrated $\mathrm{H}_{2} \mathrm{SO}_{4}$ was carefully added to the mixture to form a layer. An interface with a reddish brown coloration was formed for the presence of terpenoids.

\section{RESULTS AND DISCUSSION}

I. Qualitative analysis of phytochemical substance screening in seaweed Sargassum wightii

In the present study, the phytochemical screening was performed with chloroform, ethanol, methanol, acetone and water extracts of Sargassum wightii. The important 
phytochemical viz alkaloids, phenols, flavonoids, anthraquinones, tannins, saponins, coumarins, carbohydrate, proteins, quinines, glycosides and terpenoids were screened qualitatively for their presence or absence of above compounds in five different above said solvents extracts of seaweed Sargassum wightii, and the results were summarized and presented in Table: 1

Thus out of $(12 \times 5=60) 60$ tests for the presence or absence of the above compounds, twenty test gave positive results and the remaining 40 gave negative results (Table:1).The twenty positive results showed the presence of phenols, flavonoids, anthraquinones, tannins, saponins, carbohydrate, proteins and quinines with varied degree. Alkaloids, Coumarins, Glycosides and Terpenoids did not show any positive results for their presence in any of the tested five extracts of sargassum wightii. Among the five different extracts tested, acetone extract failed to show the absence of all the compounds except flavonoids. In this preliminary phytochemical analysis methanol and water shows the presence of maximum biochemical compounds. Chloroform and Methanol extracts shows the minimum presence of compounds.

Among the solvent extracts of seaweed Sargassum wightii showed the maximum presence of saponins, carbohydrate, proteins and quinines in three different extracts (ethanol, methanol, water) except acetone and chloroform. Chloroform extract showed the presence of three compounds like phenols, tannins and proteins. Next of chloroform acetone showed the presence of only one compound (flavonoids). Among the five different extracts tested methanol and water showed the presence of maximum number (6/12) of compounds. Proteins group showed the maximum presence in four different extract followed by saponins, carbohydrate and quinines. Phenolic group and tannins group showed the maximum presence in two different extracts chloroform and water. Most of the bioactive compounds like flavonoids, anthraquinones, carbohydrate, proteins, and quinines are found whereas compounds like phenols, tannins, saponins are meagrely found and compounds like alkaloids, coumarins, glycosides and terpenoids are not found.

Chloroform extract revealed the presence of phenols, tannins and proteins. Ethanol extract had given positive result for the presence of saponins, carbohydrate, proteins and quinines. Methanol extract had given the positive result for the presence of flavonoids, anthraquinones, saponins, carbohydrate, proteins and quinines. Acetone extract showed the 
presence of flavonoids. Water extract showed the presence of phenols, tannins, saponins, carbohydrate, proteins and quinines. (Table: 1 ) from the above results it is concluded that the presence or absence of the phytochemicals depends upon the solvent medium used for extraction and the physiological aspect of the seaweed selected. The presence or absence of different bioactive chemical constituents in extracts was responsible for different biological activities. The coastal and marine environment offers very rich source of important compounds of structurally novel and biological active metabolites (Anake and Pichan, 2004). Sargassum wightii shows a good amount of flavonoids in support of its antioxidant activity; which indicate that this genus is an ideal target for investigating presence of bio-molecules for various medical and industrial applications. In recent years, the secondary metabolites (phytochemicals) of Sargassum wightii have been extensively investigated as a source of medicinal agents. These are non-nutritive chemicals like including alkaloids, polypeptides, cyclic peptide, polysaccharide, phlorotannins, diterpenoids, sterols, quinines, lipids and glycerols that have a broad range of biological activities that have protected human from various diseases.

Table: 1 Phytochemicals screening of different solvent extracted seaweed Sargassum wightii

\begin{tabular}{|l|l|l|l|l|l|l|}
\hline S.No & Phytochemical & Chloroform & Ethanol & Methanol & Acetone & Water \\
\hline $\mathbf{1}$ & Alkaloids & - & - & - & - & - \\
\hline $\mathbf{2}$ & Phenols & + & - & - & - & + \\
\hline $\mathbf{3}$ & Flavonoids & - & - & + & + & - \\
\hline $\mathbf{4}$ & Anthraquinones & - & - & + & - & - \\
\hline $\mathbf{5}$ & Tannins & + & - & - & - & + \\
\hline $\mathbf{6}$ & Saponins & - & + & + & - & + \\
\hline $\mathbf{7}$ & Coumarins & - & - & - & - & - \\
\hline $\mathbf{8}$ & Carbohydrate & - & + & + & - & + \\
\hline $\mathbf{9}$ & Proteins & + & + & + & - & + \\
\hline $\mathbf{1 0}$ & Quinines & - & + & + & - & + \\
\hline $\mathbf{1 1}$ & Glycosides & - & - & - & - & - \\
\hline $\mathbf{1 2}$ & Terpenoids & - & - & - & - & - \\
\hline
\end{tabular}

*Abbr: $-=$ Absent, + = Presence 


\section{EPRA International Journal of Research and Development (IJRD)}

Volume: 6 | Issue: 5 | May 2021

- Peer Reviewed Journal

\section{Qualitative analysis of phytochemical substance screening in seaweed}

\section{Padina gymnospora}

In the present study the phytochemical screening was performed with chloroform, ethanol methanol, acetone and aqueous, extracts of brown marine algae Padina gymnospora for the presences and absence of alkaloids, phenols, flavonoids, anthraquinones, tannins, saponins, coumarins, carbohydrate, proteins, quinines, glycosides and terpenoids . The results were depicted in Table -2 .

Out of the sixty tested extracts, forty test showed the presence of alkaloids, phenols, flavonoids, anthraquinones, tannins, saponins, coumarins, carbohydrate, proteins, quinines , glycosides and terpenoids while twenty test showed the absence of flavonoids, anthraquinones, saponins, coumarins, carbohydrate, proteins, quinines, glycosides and terpenoids. Among the secondary metabolites analysed Alkaloid showed its presence in chloroform, ethanol, methanol and its absence in acetone and aqueous extract i.e. water. According to (Eluvakkal et al., 2010)seaweeds which are known as therapeutics, if rich in secondary metabolite like flavonoids and alkaloids are of great healing value and have been broadly used in the drug and pharmaceutical industries.

Table: 2 Phytochemicals screening of different solvent extracted seaweed Padina gymnospora

\begin{tabular}{|c|c|c|c|c|c|c|}
\hline S.No & Phytochemical & Chloroform & Ethanol & Methanol & Acetone & Water \\
\hline $\mathbf{1}$ & Alkaloids & + & + & + & - & - \\
\hline $\mathbf{2}$ & Phenols & + & + & + & + & + \\
\hline $\mathbf{3}$ & Flavonoids & - & + & + & + & + \\
\hline $\mathbf{4}$ & Anthraquinones & - & - & - & + & - \\
\hline $\mathbf{5}$ & Tannins & + & - & + & + & + \\
\hline $\mathbf{6}$ & Saponins & - & + & + & + & + \\
\hline $\mathbf{7}$ & Coumarins & - & + & + & + & + \\
\hline $\mathbf{8}$ & Carbohydrate & - & + & + & + & + \\
\hline $\mathbf{9}$ & Proteins & - & + & + & + & + \\
\hline $\mathbf{1 0}$ & Quinines & - & - & + & + & + \\
\hline $\mathbf{1 1}$ & Glycosides & - & + & + & + & - \\
\hline $\mathbf{1 2}$ & Terpenoids & - & + & + \\
\hline
\end{tabular}

\footnotetext{
*Abbr: (-) - Absent; (+) - Presence,
} 
Phenolics are the largest group of phytochemicals and have been doubted as accounting for most of the antioxidant activity of seaweed or seaweed products. The phytochemical screening of selected seaweed Padina gymnospora showed the presence of major secondary metabolite phenol in all the extracts which was similar to the report of (Wang et al. 2009) who too found phenols to be plentiful in Icelandic seaweeds. In general, phenolic compounds possess specific physical, chemical and biological activities that make them useful as drugs. Phenolics were also responsible for the antimicrobial, antiinflammatory, anti-feedant, anti-viral, anticancer and vasodilatory actions.

The results of the qualitative phytochemical screening carried out on various extracts of Padina gymnospora showed the presence of flavonoids in ethanol, methanol, acetone and water and absence in chloroform. Flavonoids are the major groups of phenolic compound reports for their antimicrobial, antiviral and spasmolytic activity.

Flavonoids has the ability of scavenging hydroxyl radical, superoxide anion radicals and lipid peroxy radicals highlights many of the flavonoid health promoting function in organisms, which are important for prevention of diseases associated with oxidative damage of membrane, proteins and DNA. Flavonoids in human diet may reduce the risk of various cancer as well as preventing menopausal symptoms (Cushnie and Lamb 2005; De Sousa et al., 2007). The result of phytochemical screening of Padina gymnospora showed the presence of Anthraquinones in the ethanol and acetone extracts and absence in chloroform, methanol and aqueous water extracts.

From Table: 2 it is revealed that Tannins, one of the major chemical constituent of the seaweeds are noted to be present in chloroform, ethanol and methanol extracts. Tannins which are of great medicinal values are moderately present in the selected seaweed Padina gymnospora. The present study observation states that this seaweed can be extensively used in drug and pharmaceutical industry. Moreover the present study result coincides with the previous observation made by (Eluvakkal et al., 2010. Kolodziej and Kiderlen, 2005) in his study on phytochemical screening stated that tannins in seaweed are found to have antiviral, antibacterial, antiulcer and antioxidant property. Tannins exhibit antiviral, antibacterial and anti-tumor activities. It has also been reported that certain tannins are able to inhibit HIV replication selectively and is also used as a diuretic. 
Saponin is used as mild detergents and it is utilized in hyper-cholesterolaemia, hyperglycaemia, antioxidant, and anti-cancer, anti-inflammatory and anti-fungal properties thereby reducing congestive heart failure, anti-carcinogenic, immune modulatory and cholesterol lowering activity (Sodipo et al., 1991; Oloyede.2005). During the present investigation the phytochemical analysis of Padina gymnospora revealed that saponin was present in ethanol, methanol and acetone extracts while they were noted to be absent in extracts of chloroform and water. (Selvi et al., 2014) showed the presents of remarkable amount of Tannin, Phenols and Saponins in the seaweeds of Sargassum wightii, Ulva fasciata and Padina gymnospora. Quinones was absent in the brown seaweed like P. gymnospora. The phytochemical screening of the all selected seaweeds showed that the seaweeds contained carbohydrates, protein, gums and mucilage, phenols, starch. The presence or absence of the phyto constituents depends upon the solvent medium used for extraction and the physiological aspect of the sea weeds selected.

\section{CONCLUSION}

The seaweeds like other marine organisms are a rich source of secondary metabolites that may be used as drugs as such or they may be starting material for the development of new drugs. Hence it is very important to have quality control parameters for each seaweed. Therefore, results obtained from the present study, it can be concluded that the presence of alkaloids, phenolics, flavonoids, saponins, carbohydrates, coumarines, qunines, and tannins from Sargassum wightii, Padina gymnospora showed a number of active secondary metabolites. In the food, pharmaceutical, cosmetic, cosmeceutical, nutraceutical and biomedicine industries, seaweed/macroalgae are used as a valuable source of bioactive compounds.

\section{REFERENCES}

1. Adikalaraj G, Johnson M, Patric RD, Janakiraman N. Pharmacognostical and phytochemical evaluation of selected seaweeds of Rhodophyceae. Natural Products. 2011; 7(6):1-9.

2. Anake, K. and Pichan, S. (2004). Drugs and cosmetics from the sea. Marine Drugs.73- 82.

3. Awad NE, Selim MA, Metawe HM, Matloub AA. Cytotoxic xenicane diterpenes from the brown alga Padina pavonia (L.) Gaill. Phytotherapy Research. 2008; 22(12):1610-1613.

4. Baliano AP, Pimentel EF, Buzin AR, Vieira TZ, Romão W, Tose LV et al. Brown seaweed Padina gymnospora is a prominent natural wound-care product, Brazilian Journal of Pharmacognosy. 2016; 26:714-719.

5. Becerro, M.A., N.I. Lopez, X. Turon and M.J. Uniz, 1988. Antimicrobial activity from marine and freshwater microalgae in laboratory culture. British Phycological Journal. 23: 45-47. 
6. Chander MP, Veeraragavam S, Vijayachari P. Antimicrobial and Hemolytic activity of seaweed Padina gymnospora from South Andaman, Andaman and Nicobar Islands of India. International Journal of Current Microbiology and Applied Sciences. 2014; 3:364-369.

7. Cushnie, T.P.T. and Lamb, A.J. (2005). Antimicrobial activity of flavonoids. International Journal of Antimicrobial Agents.26(5): 343-356.

8. De Sousa, R.R., Queiroz, K.C., Souza, A.C., Gurgueira, S.A., Augusto, A.C. and Miranda ,M.A. (2007). Phosphoprotein levels, MAPK activities and NFkappaB expression are affected by fisetin. Journal of Enzyme Inhibition and Medical Chemistry .22 (4): 439-444.

9. Devi JA, Balan GS, Pariyanayagam. Pharmacognostic study and physicochemical evalution of brown seaweed Sargassam wightii. Journal of Coastal Life Medicine. 2013; 1(3):199-204.

10. Dhanki A, Pande J, Donga S, Chanda S. Pharmacognostic standardization of Chaetomorpha antennina and Ulva lactuca, green seaweeds from Gujarat coast. Journal of Pharmacognosy and Phytochemistry. 2018; 7(2):3863-3870.

11. El Gamal AA. Biological importance of marine algae. Saudi Pharmaceutical Journal. 2010; 18(1):1-25.

12. El Shoubaky GA, Salem EA. Active ingredients fatty acids as antibacterial agent from the brown algae Padina pavonica and Hormophysa triquetra. Journal of Coastal Life Medicine. 2014; 2(7):535-542. http://dx.doi.org/10.12980/JCLM.2.2014JCLM-2014- 0025.

13. Eluvakkal, T., Sivakumar, S.R. and Arunkumar, K. (2010). Fucoidan in some Indian brown seaweed found along the Coast of Gulf of Mannar. International Journal of Botany. 6(2):176-181.

14. Gulcin I, Buyukokuroglu MF, Oktay M, Kufrevioglu IO. (2002). On the in-vitro antioxidant properties of melatonin. J Pineal Res, 33: 167-171.

15. Hernández-Herrera RM, Santacruz-Ruvalcaba F, ZañudoHernández J, Hernández-Carmona G. Activity of seaweed extracts and polysaccharide-enriched extracts from Ulva lactuca and Padina gymnospora as growth promoters of tomato and mung bean plants. Journal of Applied Phycology. 2016; 28(4):2549-2560.

16. Jaswir I, Noviendri D, Salleh HM, Taher M, Miyashita K. Isolation of fucoxanthin and fatty acids analysis of Padina australis and cytotoxic effect of fucoxanthin on human lung cancer (H1299) cell lines. African Journal of Biotechnology. 2011; 10(81):18855-18862.

17. Joshi NVM, Srisudha S. Biochemical characterization, haemagglutinating activity and cytotoxic activity of Padina gymnospora (Kutzing) Sonder. International Journal of Biological and Pharmaceutical Research. 2012; 3(8):956-961.

18. Kanjana, K., Radtanatip, T., Asuvapongpatana, S., Withyachumnarnkul, B. and Wongprasert, K. 2011. Solvent extracts of the red seaweed Gracilaria fishri prevent Vibrio harveyi infections in the black tiger shrimp Penaeus monodon. Fish and Shellfish Immunology. 30: 389-396.

19. Kolodziej, H. and Kiderlen, A.F. (2005). Antileishmanial activity and immune modulatory effects of tannins and related compounds on Leishmania parasitised RAW 264.7 cells. Phytochemistry. 66(17):2056-2071.

20. Krishnaveni ,K., Mureshkumar, D.J., Balakumaran, M.D., Ramesh, S. and kalaichelvan, P.T.( 2012). Production and optimization of extrcellular alkaline protease from bacillus subtilis isolated from dairy effulent. Der Pharmacia Lett.4(1)98-109 Lala, P,K. (1993). Lab manuals of Pharmacognosy. CSI publishers and distributers, Calcutta.

21. Lala, P,K. (1993). Lab manuals of Pharmacognosy. CSI publishers and distributers, Calcutta.

22. Murugan K, Iyer VV. Antioxidant activity and gas chromatographic-mass spectrometric analysis of extracts of the marine algae, Caulerpa peltata and Padina gymnospora. Indian Journal of Pharmaceutical Sciences. 2014; 76:548-552.

23. Murugan, A. and M. Santhana Ramasamy, 2003. Biofouling deterrent natural product from the ascidian Distaplianathensis. India Journal of MarineScience.32: 162-64. 
24. Oktay M, Gulçin I, Kufrevioglu OI. (2003). Determination of in vitro antioxidant activity of fennel (Foeniculum vulgare) seed extracts. Lebensm Wiss Technol, 36:263-271.

25. Oloyede, O. O. I. (2005). Chemical profile of Unripe Pulp of Carica Papaya. Pak. J. Nutr. 4(6): 379-381.

26. Rangaiah SG, Lakshmi P, Manjula E. Antimicrobial activity of seaweeds Gracillaria, Padina and Sargassum sp. on clinical and phytopathogens. International Journal of Chemical and Analytical Science. 2010; 1(6):114-117.

27. Sadasivam, S. and Manickam, A. (1996). Biochemical methods for agricultural sciences, New age International $(P)$ Ltd., New Delhi, India, 1-97.

28. Selvi, V., Alagesan, P. and Kulandaivel, S. (2014). Study on phyto-chemical and antimicrobial activity of some selected marine seaweeds against human and fish pathogens. Innovare Journal of Ayurvedic Science. 2(1): 1-5.

29. Silva TM, Alves LG, De Queiroz KC, Santos MG, Marques CT, Chavante SF et al. Partial characterization and anticoagulant activity of a heterofucan from the brown seaweed Padina gymnospora. Brazilian Journal of Medical and Biological Research. 2005; 38(4):523-533.

30. Sodipo, O.A., Awanji, M. A., Kolawole, F. B., and Oduntuga, A. A. (1991). Saponin is the active fungal principle in Garcinia kola, Hekle seed. Bioscence Biotechnology Research communications. (3):171.

31. Sri Ramkumar V, Pugazhendhi A, Prakash S, Ahila NK, Vinoj G, Selvam S et al. Synthesis of platinum nanoparticles using seaweed Padina gymnospora and their catalytic activity as PVP/PtNPs nanocomposite towards biological applications. Biomedicine and Pharmacotherapy. 2017; 92:479-490.

32. Sumithra M, Arunachalam G. Pharmacognostical studyand phytochemical evaluation of Sargassum ilicifolium (Turner) C. Agardh. International Journal of Pharm Tech Research. 2014; 6(7):2022-2027.

33. Trease GE, Evans MD. A text book of Pharmacognosy, 13th Edn.Baillier, Tindal and Caussel, London.1989, 144-148.

34. Wang, T., Jonsdottir, R. and Olafsdottir, G. (2009). Total phenolic compounds, radical scavenging and metal chelation of extracts from Icelandic seaweeds. Food chemistry. 116:240-248. 